\title{
Research Paper \\ Role of Social Skills in Predicting the Students' Sense of Coherence and Quality of School Life
}

\author{
Effat Saneie*1, Mohammadreza Raeisoon ${ }^{2}$ \\ 1. M.A. in Primary Education, Ferdows Branch, Islamic Azad University, Ferdows, Iran \\ 2. Assistant Professor, Department of Psychology, School of Medicine, Birjand University of Medical Sciences, Iran
}

Citation: Saneie E, Raeisoon M. Role of social skills in predicting the students' sense of coherence and quality of school life. Quarterly Journal of Child Mental Health. 2020; 7(2): 96-107.

http://dx.doi.org/10.29252/jcmh.7.2.9

\section{A R T I C L E I N F O}

\section{Keywords:}

Social skills, sense of coherence, quality of school life

Received: 8 Mar 2020 Accepted: 18 Jun 2020 Available: 21 Sep 2020

\begin{abstract}
A B S T R A C T
Background and Purpose: Due to the importance of children's and adolescents' quality of school life, the World Health Organization has raised the issue concerning the necessity of improving the quality of school life, which includes the students' welfare and their satisfaction with positive experiences in school activities. Therefore, present research aimed to investigate the role of social skills in predicting the sense of coherence and quality of school life in grade 6 students in Tabadkan district.

Method: This research was a descriptive-correlational study. The study population included all the male and female grade 6 primary school students in Tabadkan during the academic year 2018-2019. A sample of 384 students was selected by convenience sampling. Social Skills Questionnaire (Keramati, 2007), Sense of Coherence Scale (Antonovsky, 1993), and Quality of School Life Scale (Ainley \& Bourke, 1989) were used to collect the data. Pearson regression coefficient and simultaneous multiple linear regression were used to analyze the data with SPSS 22 .

Results: Data analysis showed that there was significant positive relationship between sense of coherence and quality of school life ( $\mathrm{P}<0.001)$. Also, dimensions of social skill explained $21.4 \%$ of sense of coherence and $17.4 \%$ of quality of school life $(\mathrm{P}<0.001)$.

Conclusion: Results of this study showed that improving the social skills can increase the student's sense of coherence and quality of school life. Implications of results are discussed in the article.
\end{abstract}

\footnotetext{
* Corresponding author: Effat Saneie, M.A. in Primary Education, Ferdows Branch, Islamic Azad University, Ferdows, Iran. E-mail addresses: E.sanei.1399@gmail.com
} 


\section{نقش مهارتهاى اجتماعى در بيشينى انسجام روانى و كيفيت زندكى دانش آموزان در مدرسه}

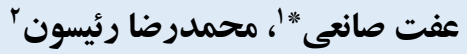

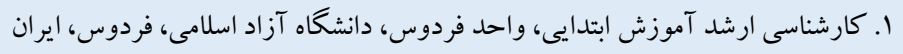

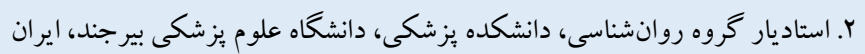

\section{جكيده}

زمينه و هدف: سازمان سلامت جهانى به دليل اهميت كيفيت زندگى كودكان و نوجوانان در مدرسه، موضوع بهزيستى و رضايت كلى دانش آموزان از تجارب مثبت و منفى در فعاليتهاى درون مدرسه را مطرح كرده است. در نتيجه شناسايى عوامل مرتبط با كيفيت زندگى دانش آموزان داراى اهميت بسيار زيادى است. بدين ترتيب هدف مطالعه حاضر بررسى نقش مهارتهاى اجتماعى در ييشينى انسجام روانى

$$
\text { و كيفيت زندگى در مدرسه دانش آموزان بايه ششم ابتدايى بود. }
$$

روش: يُزوهش حاضر از نوع توصيفى- همبستخى بود. جامعه آمارى اين مطالعه شامل تمامى دانش آموزان دختر و يسر بايه ششم ابتدايى

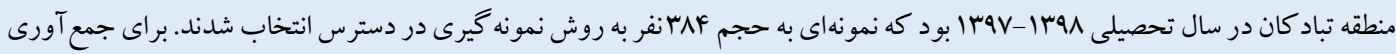

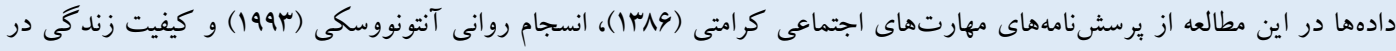

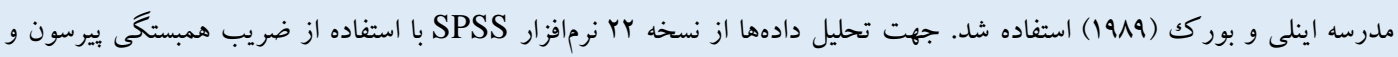

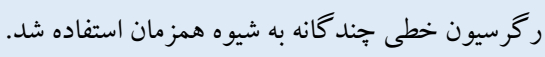

يافتها: نتايج تحليل دادهها نشان داد بين مهارتهاى اجتماعى با انسجام روانى و كيفيت زندگى در مدرسه، رابطه مثبت و معنادارى وجود

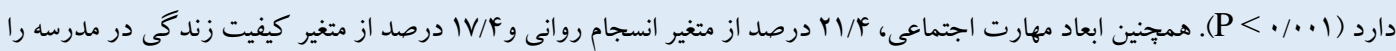

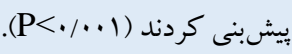

نتيجه كيرى: نتايج اين مطالعه نشان داد كه با افزايش و بهبود مهارتهاى اجتماعى، انسجام روانى و كيفيت زندكى دانش آموزان در مدرسه

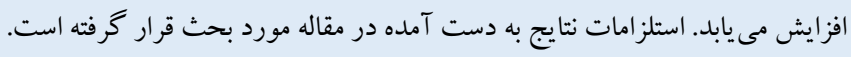

مشخصات مقاله

كليدوازهها:

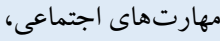

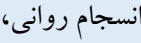

كيفيت زندگى در مدرسه

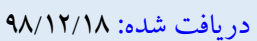

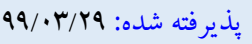

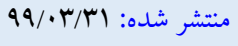

* نويسنده مسئول: عفت صانعى، كارشناسى ارشد آموزش ابتدايى، واحد فردوس، دانشكاه آزاد اسلامى، فردوس، ايران.

راياناه: E.sanei.1399@gmail.com 
انســـام روانى در افراد نوجوان و جوان، رابطه مثبت و معنادارى وجود

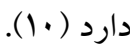

از روش هاى موثر در بهبود ويز گى هاى روانشــاختى ماند انسـجام

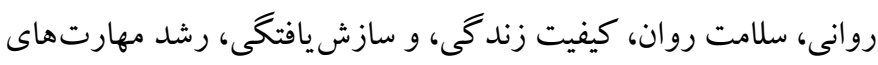

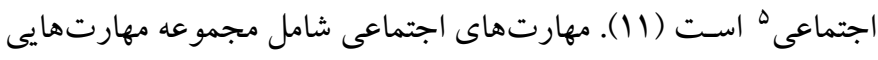

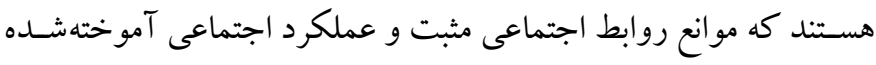

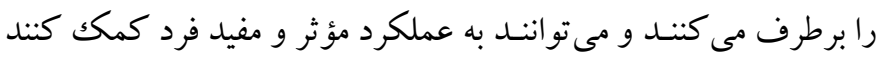

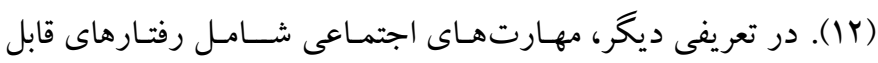

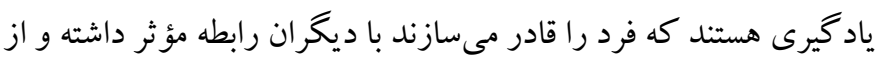
عكس العمل هـاى نـامعقول اجتمـاعى خوددارى كنــ و از مهم ترين اين مهارتها مى توان همكارى، مشار كت با ديخران، كمك كردن، آغاز گرك

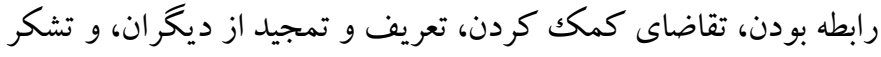

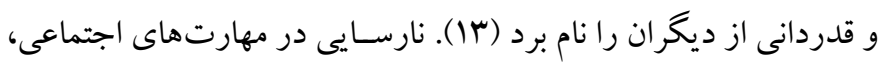

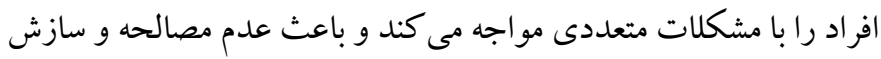
در روابط بينفردى، مشـكلات، و اختلالات رفتارى مى شــود و بر تحول شـخصـيت كود كك و سـازش يذيرى وى با محيط، تأثير منفى مى كذارد

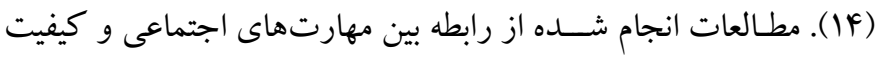

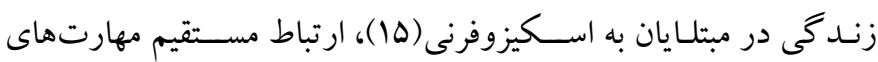

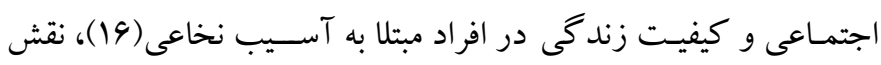

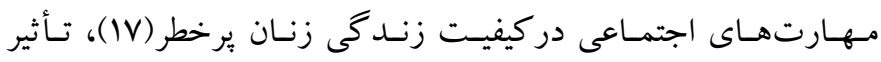
مهارتهـاى اجتمـاعى بر كيفيت زندگى كود كان با تومور مغزى (1) (1)،

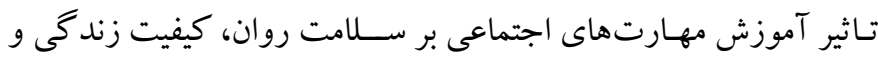

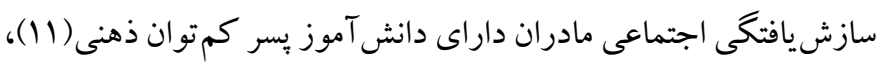
نقش مهارتهاى روانشـناختى و اجتماعى در انسـجام تيمى بازيكنان

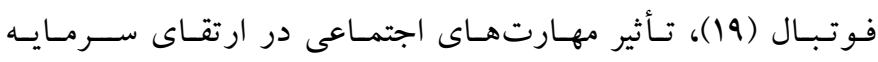
روانشــــاختى (تـابآورى، اميـد، خـوشبينى، و خودكـار آمـدى)

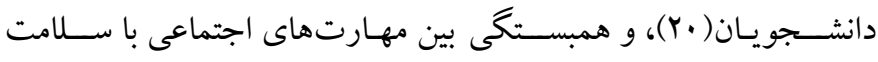

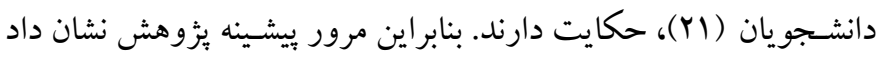

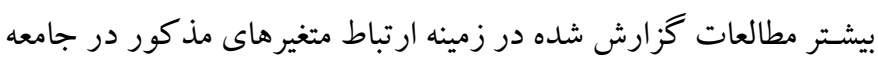

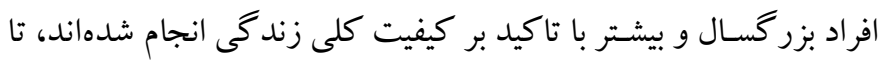

4. Psychological Cohesion

5. Development of Social Skills
مقدمه

اخيراً سـازمان سـلامت جهانى' به دليل اهميت كيفيت زندكى كود كان و

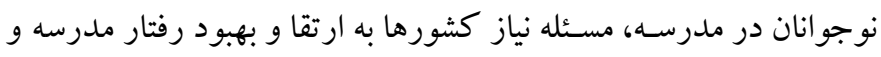

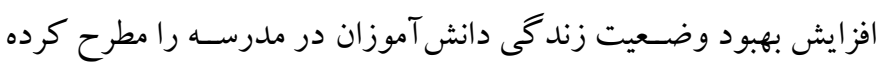

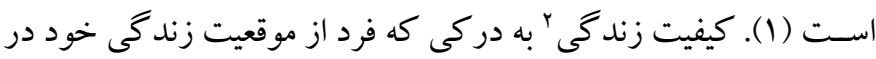
بافت فرهنگى و نظام ارزشى كه در آن زندگى مى كند، اشاره دارد (Y).

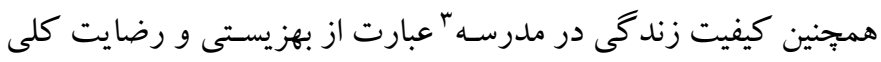

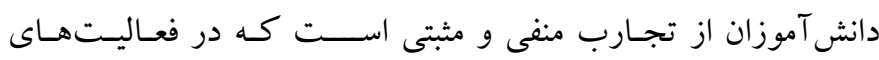
درونمدرسهاى آنها ريشه دارد. اين تجارب مثبت و منفى كه شكل ملئى دهنده

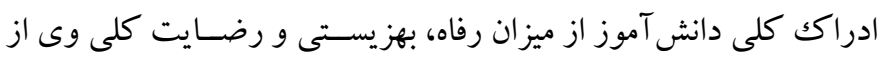

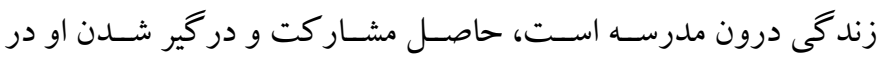

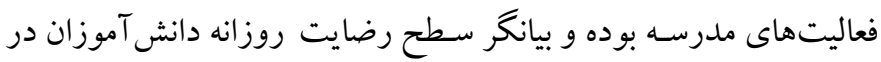

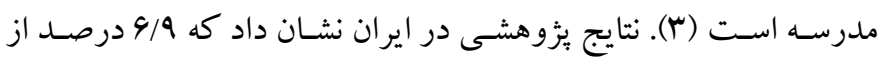

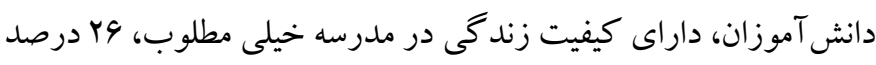

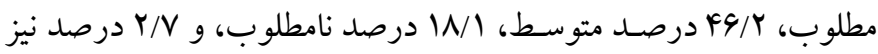
كيفيت زندگى در مدرسه خيلى نامطلوب داشتند(f).

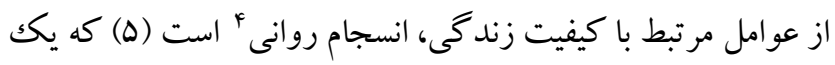

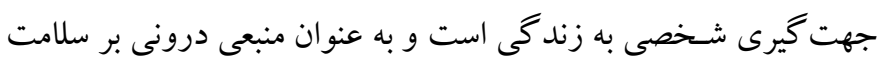

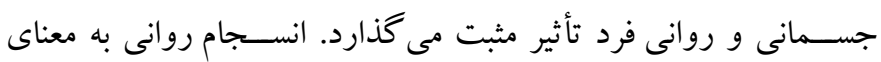

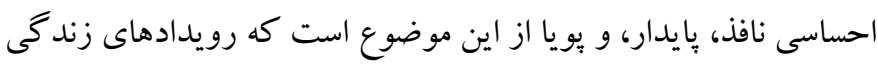

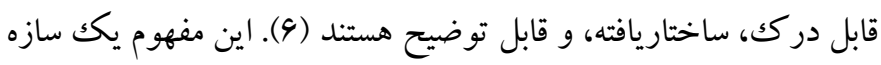

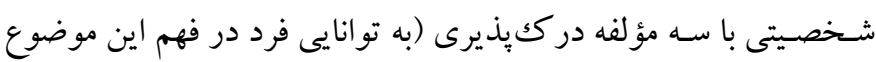

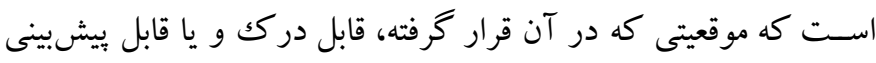

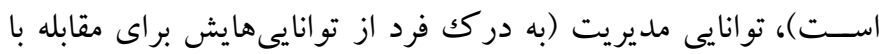

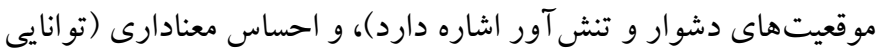

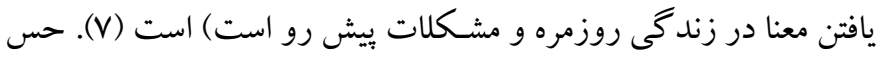

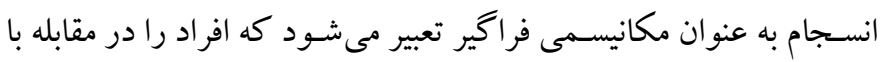

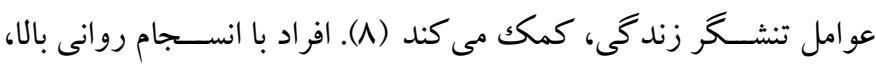

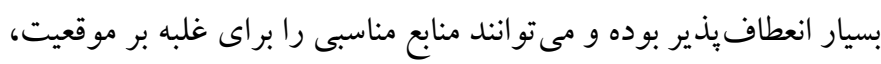

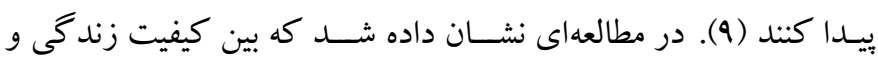

1. World Health Organization

2. Quality in School

3. Life Quality in School 
مرحلـه اول از بين مــدارس منطقـهـ تبـادكـان، جهار آموزشـــاه از جِهار

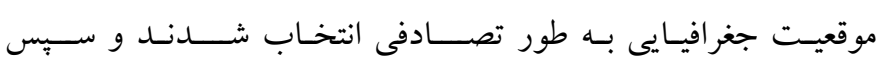

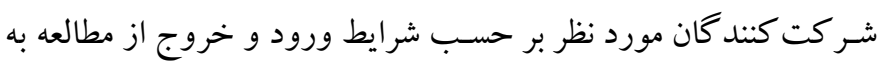

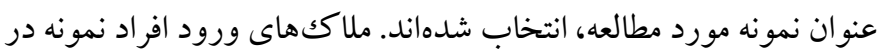

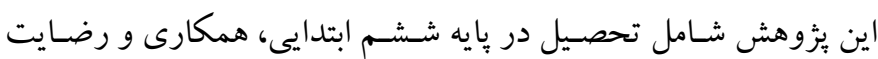

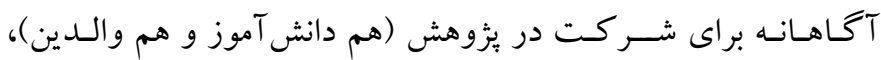

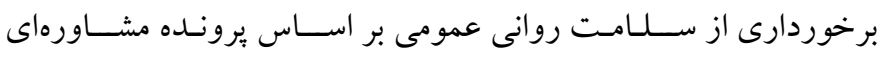

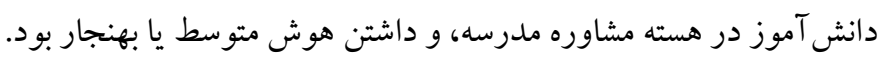

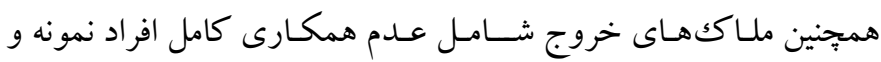

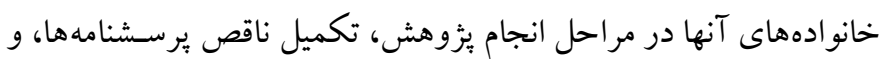

$$
\text { مصرف داروهاى روانيزشكى بود. }
$$

لازم به ذكر است كه از بين افراد نمونه مورد مطالعه در اين بئوهش، بودي،

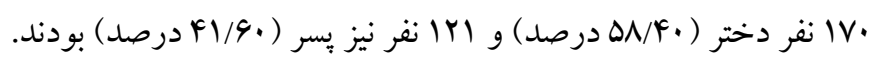

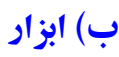

ا ـ مقياس مهارتهاى اجتماعى': بر ســـــامه مهارت هاى اجتماعى مورد

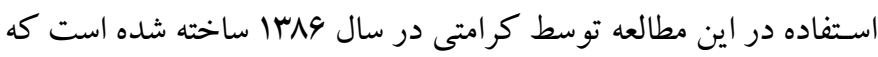
داراى •F كويه است و مؤلفه هاى مهارتهاى مربوط به احترام به ديخران

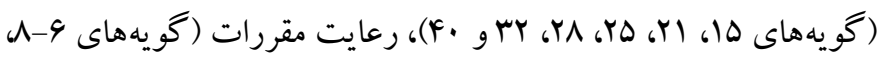

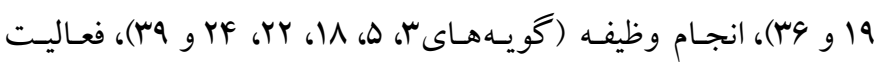

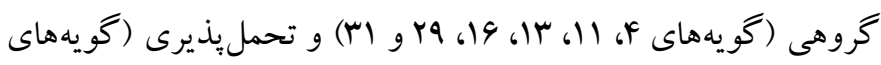
•)

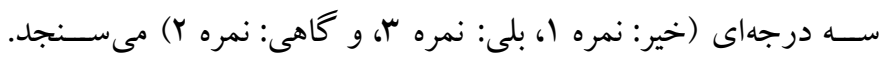

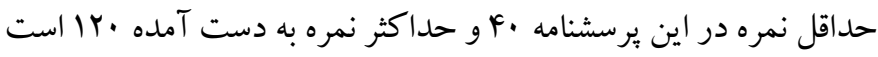

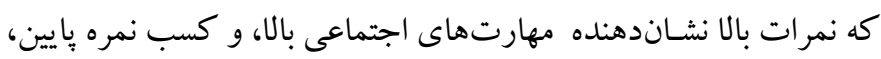

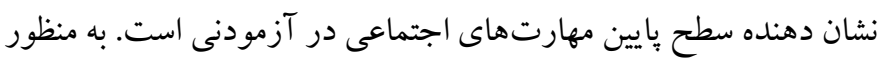

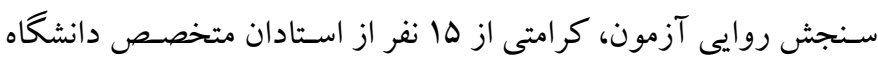

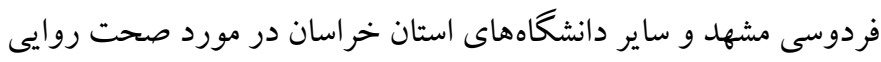

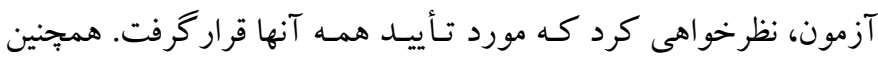

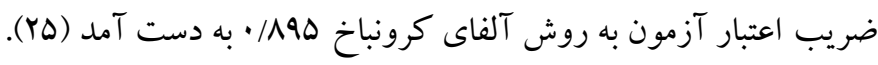
در بثزوهش محبى نور الدين وند، مشتاقى و شهبازى نيز ضريب اعتبار اين

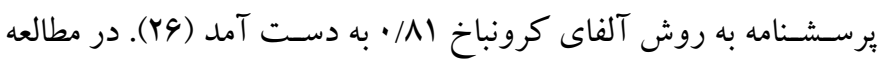

كيفيت زندگى در مدرسه؛ و در نتيجه بزوهش هاى اندكى درباره كيفيت زندگى دانش آموزان در مدرسه انجام شده است.

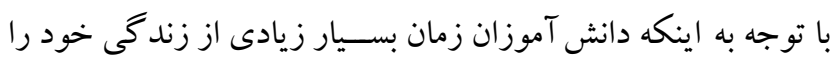

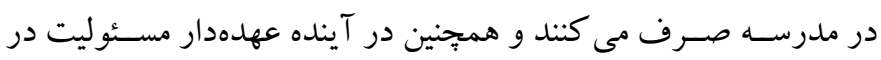

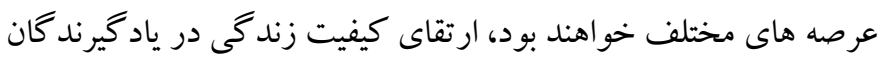
به دليل نقش اثر گذار آن بر سلامت روانى و جسمى، نيازمند ارزيابى دقيق

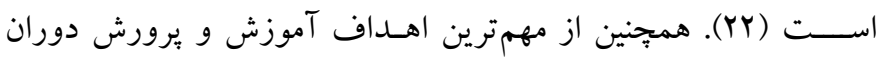

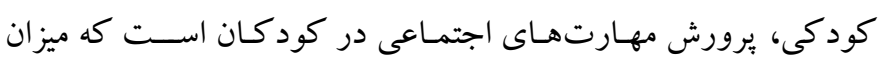

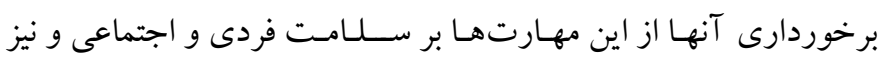

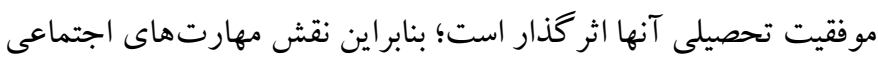

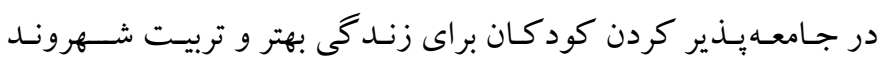

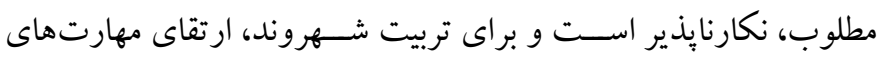

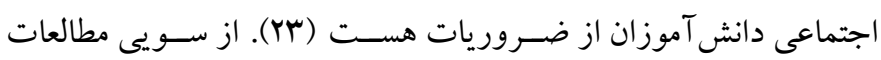
يزروهشى انجام شده در حيطه مهارتهاى اجتماعى درباره ارتباط مستقيم

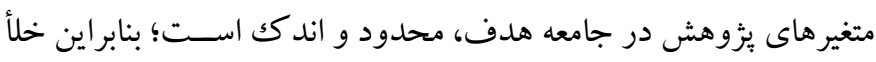

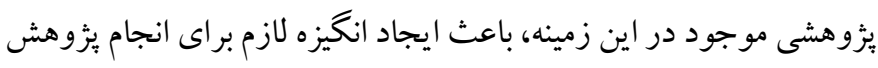

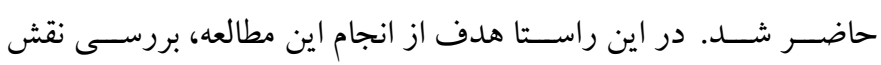

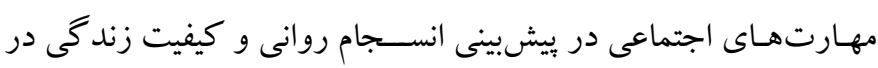
مدرسه دانش آموزان بايه ششم ابتدايى بود.

ووش

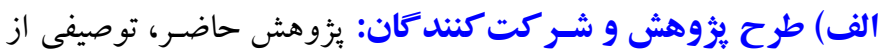

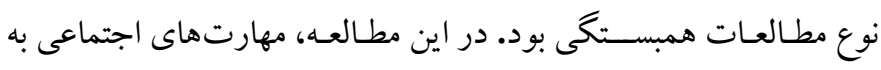

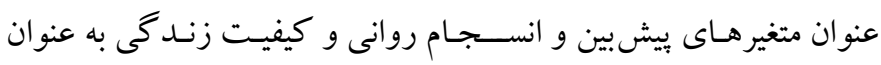

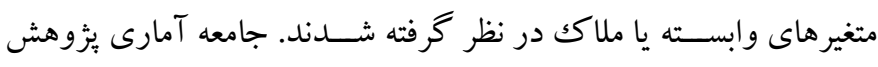
شـامل تمامى دانش آموزان دختر و پِسر پيايه ششم ابتدايى منطقه تباد كان

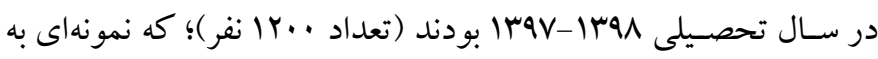

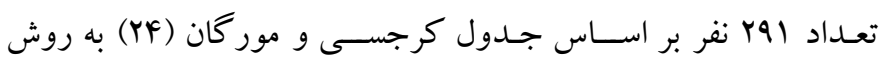

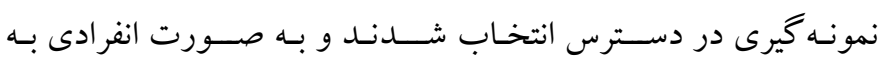

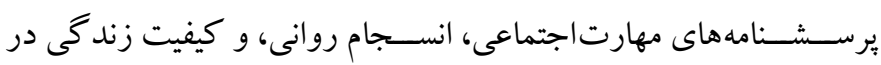

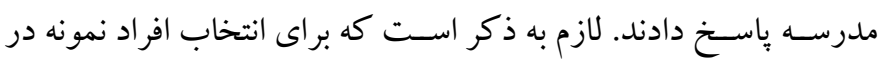

1. Social skills scale 
كاملاً موافقم: نمره F) مىســجد. اينلى و بوركك روايى اين ابزار را مورد

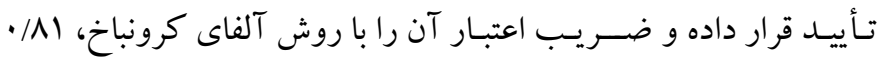

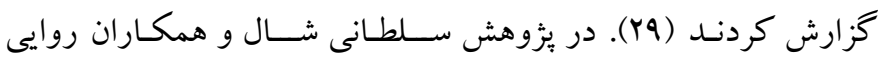

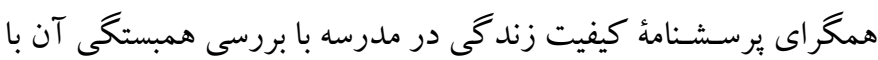

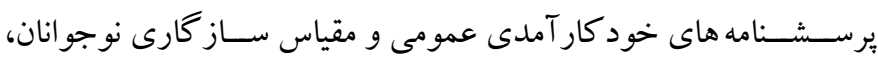

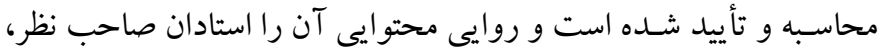
تأييد كردهاند. همجنين ضــريب اعتبار اين ابزار با روش آلفاى كرونباخ

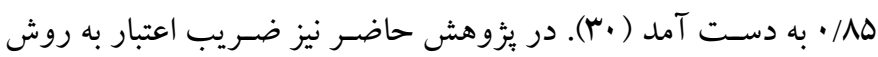
آلفاى كرونباخ، مه/ • به دست آمد.

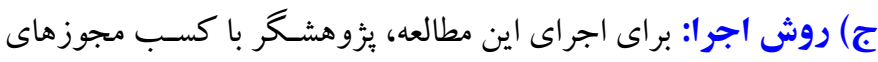

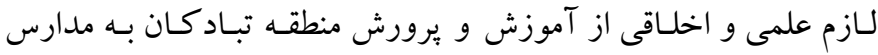

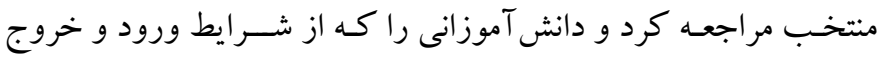
مورد نظر در اين يزوهش برخوردار بودند به شـرحى كه در بخش روش

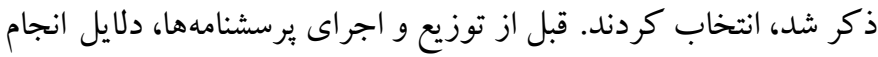

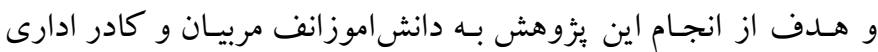

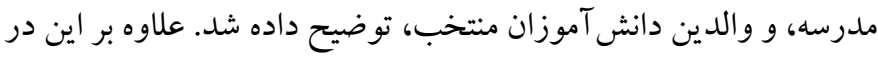
اين مطالعه، تمامى اصــول اخلاقى مرتبط مانند محرمانه بودن اطلاعات

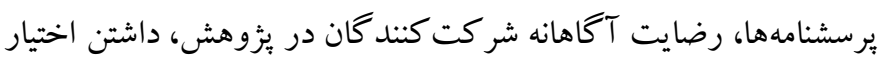
افراد نمونه براى خروج از يزوهش، رعايت شده است. براى تجزيهو تحليل

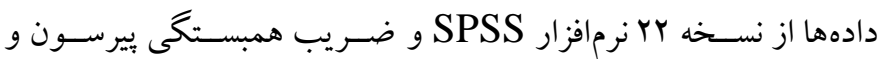

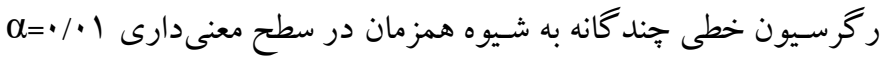
استفاده شد.

\section{يافتهها}

در جدول ا يافتهاى توصـيفى اين يزوهش شــامل ميانخين و انحراف

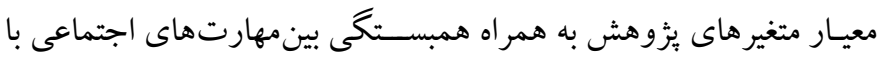
انسجام روانى و كيفيت زندگى در مدرسه گزارش شده است.
حاضــر نيز ضــريب آلفاى كرونباخ AA/ • به دسـت آمد كه مطلوب و رضايتبخش است. r. برسشنامه انسـجام روانى': اين برســـــامه كه به منظور سـنجش ميزان

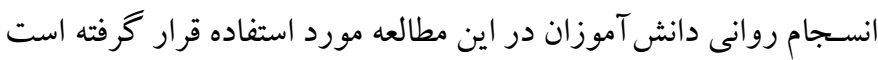

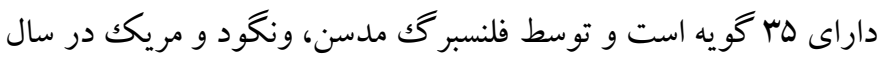

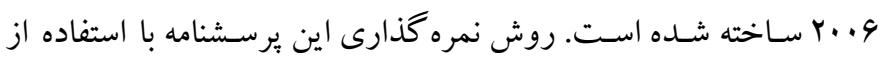
مقياس سهدرجهاى ليكرت (1=خير، ب=نمىدانم، و r=بله) انجام مى شود.

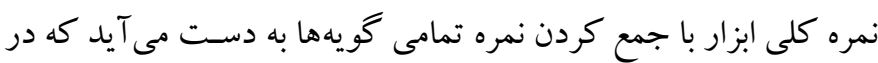

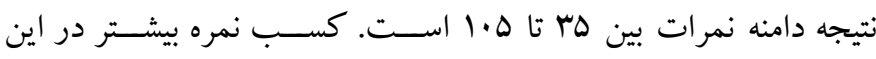
يرســــامه به معناى برخوردارى از انسـجام روانى بالاتر، و كسـب نمره

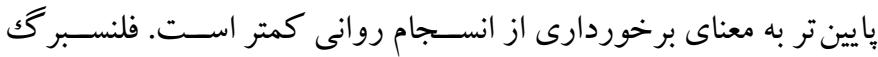

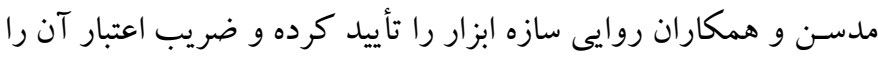
با روش آلفاى كرونباخ AV•• زاده، صبرى نظرزاده و معمارباشى اول، اعتبار اين ابزار را به روش آلفاى

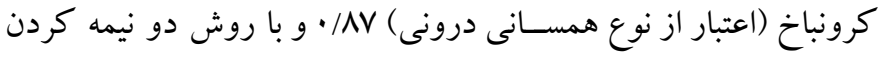

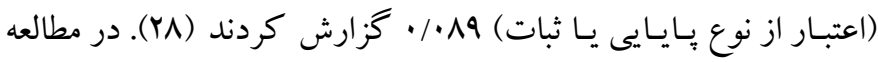

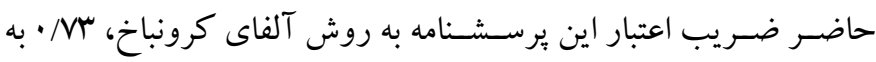
دست آمد.

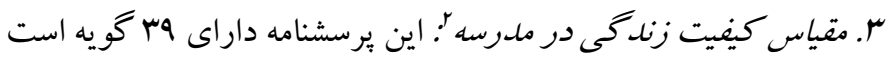

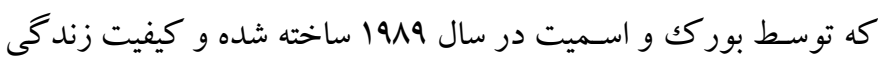
دانش آموزان در محيط مدرسـه را مىســند. مقياس كيفيت زندگى در

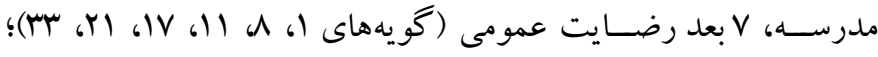

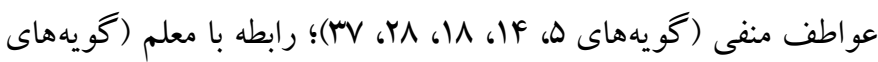

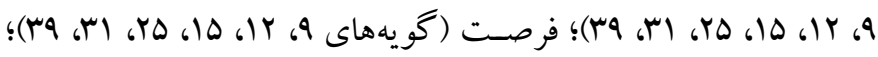

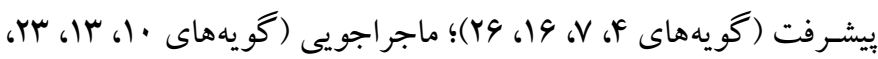
(זV

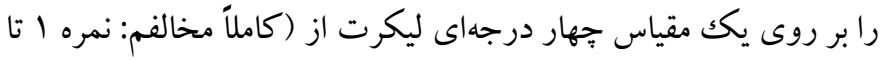


جدول ا: ماتريس ضريب همبستغى بيرسون بين مهارتهاى اجتماعى با انسجام روانى و كيفيت زند معى در مدرسه

\begin{tabular}{|c|c|c|c|c|c|c|c|c|c|}
\hline v & 7 & 0 & $\varepsilon$ & $r$ & $r$ & 1 & انحر اف معيار & ميانكين & متغير ها \\
\hline & & & & & & 1 & $Y / 19$ & $\Lambda / \cdot r$ & 1. انجاموظيفه \\
\hline & & & & & 1 & $\cdot / F \vee \Delta * *$ & $r / 11$ & $11 / r r$ & r. احترام به ديخران \\
\hline & & & & 1 & $\cdot / \mu \Delta V^{* * *}$ & $\cdot / \mu 19 * *$ & I/DF & $9 / Y Y$ & r. رعايت مقررات \\
\hline & & & 1 & - / TFF** & $\cdot / F \& \Delta * *$ & $\cdot / 4 \cdot 9 * *$ & r/l. & $\Lambda / V^{F}$ & F. فعاليت گروهى \\
\hline & & 1 &.$/ 19 \uparrow * *$ & $\cdot / r \mid r * *$ & $\cdot / r \wedge \mid * *$ & $\cdot / Y \wedge V^{* *}$ & $r / 9$. & $11 / \Delta \Lambda$ & هـ تحمل يذيرى \\
\hline & 1 & $. / 19 . * *$ & $\cdot / r \cdot v^{* *}$ & $\cdot / \Lambda \mid * *$ & • & $\cdot / r 91 * *$ & $F / V r$ & $Y F / \cdot G$ & 9. كيفيت زندگى در مدرسه \\
\hline 1 & . $/$ rAN** & $\cdot / \backslash \Lambda \cdot * *$ & $\cdot / r \wedge V^{* *}$ & . /YYV** & $\cdot / r Y \mid * *$ & - /rFF** & IS/AV & IYF/AD & V. انسجام روانى \\
\hline
\end{tabular}

براى ييشبينى انسـام روانى از روى مهارتهاى اجتماعى از روش

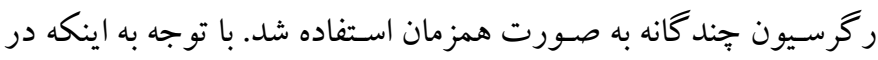
يُزوهش حاضـر فرض شـده است تمامى مهارتهاى اجتماعى به صورت

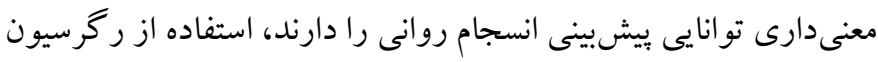

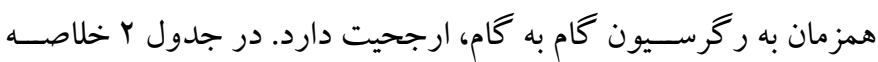

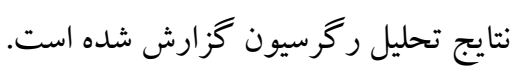

بر اســاس نتايج جدول ا ضــرايب همبســـى محاسـبه شــده بين مهارت هاى اجتماعى با انسجام روانى و كيفيت زندگى در مدرسه، مثبت

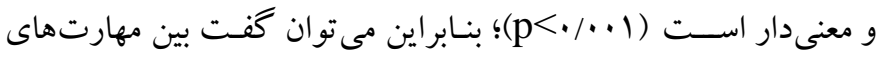
اجتماعى با انسـام روانى و كيفيت زندكى در مدرسـه، ارتباط مسـتقيم وجود دارد.

جدول ז: خلاصه نتايج مدل ييشبينى انسجام روانى از روى مهارتهاى اجتماعى

\begin{tabular}{|c|c|c|c|}
\hline خطاى استاندارد بر آورد & R Rديل شده & واريانس تبيين شده ( R & همبستكى جند \\
\hline$N / \Delta 1$ &.$/ 199$ & $\cdot / Y I F$ & . א\& \\
\hline
\end{tabular}

نتايج تحليل واريانس مدل براى بررسـى توانايى بيش بينى متغير انسـجام روانى از روى متغير بيش بين مهارتهاى اجتماعى گز ارش شده است.
با توجه به نتايج جدول Y، ضــريب همبسـتِى جند كانه مهارتهاى اجتماعى با انسجام روانى، بع/\&/ است و مهارتهاى اجتماعى در مجموع

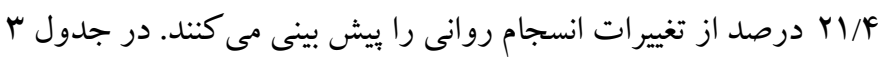

جدول ب: نتايج تحليل واريانس رگرسيون جندمتغيرى متغير ملاكى از روى متغيرهاى بيشبين

\begin{tabular}{|c|c|c|c|c|c|}
\hline سطح معنادارى & $\mathbf{F}$ & ميانكين مجذورات & درجه آزادى & مجموع مجذورات & مدل \\
\hline \multirow[t]{3}{*}{.$/ .1$} & $11 / 91$ & $199 / 9$. & $\Delta$ & FHFN/.1 & ركرسيون \\
\hline & & $V Y / \Delta Q$ & rr. & $10999 / 99$ & باقيمانده \\
\hline & & & rro & r.rIV/VI & كل \\
\hline
\end{tabular}

را دارند. در جدول \& ضـرايب اسـتاندارد شـده و اسـتاندارد نشــده تحليل ركرسيون كزارش شدهاند.

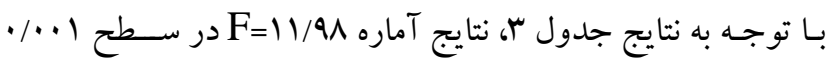
معنى دار اســــ؛ بنـابراين مى توان نتيجـه كرفـت متغيرهـاى بيشبين (مهارتهاى اجتماعى)، توانايى بيشبينى متغير ملاكك يعنى انسجام روانى 
جدول ع: ضرايب ركرسيون استاندارد نشده و استاندارد شده مدل بيش بينى انسجام روانى

\begin{tabular}{|c|c|c|c|c|c|}
\hline \multirow{2}{*}{ سطح معنادارى } & \multirow{2}{*}{$\mathbf{t}$} & \multirow{2}{*}{ ضرايب استانداردشده } & \multicolumn{2}{|c|}{ ضرايب استاندارد نشده } & \multirow{2}{*}{ مدل } \\
\hline & & & خطاى معيار & B & \\
\hline.$/ .1$ & $|\Delta / F|$ & & $r / \Delta \Lambda$ & $\Delta \Delta / r$ & ثابت \\
\hline - /AQF & ./MF &.$/ 1$ & ( &.$/ \cdot F F$ & انجاموظيفه \\
\hline$\cdot / r v$ & -/А९८ & $.1 .9 \mathrm{~V}$ & • ITYG & - rar & احترام به ديخران \\
\hline$\cdot / Y Y \Lambda$ & $1 / \Delta r$ &.$/ .99$ & •/ भ৭9 & $\cdot 19 \cdot 4$ & رعايت مقررات \\
\hline.$\cdot \cdot 1$ & $F / 99$ & $\cdot /$ rqV & · MYA & $1 / 94$ & فعاليت گروهى \\
\hline.$/ 94 F$ & . /Aq &.$/ . r$. & $\cdot / 191$ &.$/ .94$ & تحمل بذيرى \\
\hline
\end{tabular}

يعنى هر جه قدر فرد فعاليت گروهى بيشـترى داشـته باشـد، انسجام روانى

$$
\text { بيشترى دارد. }
$$

براى بيشبينى كيفيـت زنسدكى در مسدرســـه از روى مهـارت هـاى

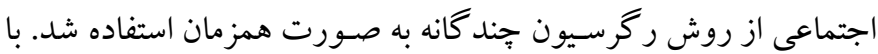
توجه به اينكه در بزظوهش حاضـر فرض شـــه اسـت تمامى مهارتهاى اجتماعى به صورت معنادارى تو انايى بيشبينى كيفيت زندكى در مدرسه را دارند، استفاده از ركرسيون همزمان به رگرسيون گام به گام ارجحيت دارد. در جدول ه خلاصه نتايج رگرسيون گزارش شده است.
بـا توجسه بـه نتايج جدول F، تأثير فعاليت گروهى بر انســام روانى (

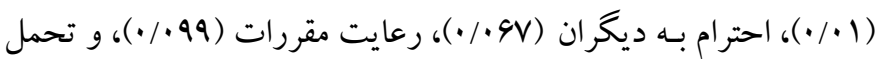
يذيرى ( •r•/• معنادار نشــــ بنابر اين از بين مهارت هاى اجتماعى، تنها فعـاليـت كروهى به طور معنادارى انســام روانى را بيشبينى مى كند و ســاير مهارت هاى اجتماعى، قابليت بيشبينى انســام روانى را ندارند. فعاليت گروهى به صسـورت مثبت انســجام روانى را بيش بينى مى كند؛

جدول 0: خلاصه نتايج مدل بيشيينى كيفيت زندكى در مدرسه از روى مهارتهاى اجتماعى

\begin{tabular}{|c|c|c|c|}
\hline خطاى استاندارد بر آورد & R تعديل شده $R^{2}$ & واريانس تبين شده ( R) & همبستگى جند كانه (R) \\
\hline $1 D / F F$ &.$/ 109$ &.$/ I V^{F}$ & ./FIV \\
\hline
\end{tabular}

بيشبينى مى كنند. در جدول 9 نتايج تحليل واريانس مدل براى بررسـى توانـايى بيشبينى متغير كيفيـت زنـدكى در مـدرســـه از روى متغيرهـاى يشين مهارت هاى اجتماعى گزارش شده است.
با توجه به نتايج جدول ه، ضــريب همبسـتِى جند كَانه مهارتهاى اجتماعى با كيفيت زندگى در مدرســه، IIV/ • اســت و مهارتهاى اجتماعى در مجموع V/F/ ادرصد از تغييرات كيفيت زندكى در مدرسه را

جدول ا: نتايج تحليل واريانس ركرسيون جندمتغيرى متغير ملاكى از روى متغيرهاى ييشبين

\begin{tabular}{|c|c|c|c|c|c|}
\hline سطح معنى دارى & $\mathbf{F}$ & ميانكين مجذور ات & درجه آزادى & مجموع مجذورات & مدل \\
\hline \multirow[t]{3}{*}{.$/ \cdot 1$} & $9 / 9 Y$ & rYAY/VD & $\Delta$ & $\| F V / V D$ & ركرسيون \\
\hline & & YMN/DF & TYA & $\Delta F T A V / T$. & باقيمانده \\
\hline & & & זחז & $90 \wedge 9 \cdot / 90$ & كل \\
\hline
\end{tabular}

زندكى در مدرســه را دارند. در جدول Vــــايب اســاندارد شــده و استاندارد نشده تحليل رگرسيون گزارش شدهاند.

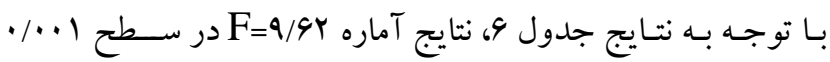
معنى دار اســــ؛ بنـابراين مى توان نتيجـه كرفـت متغيرهـاى بيشبين (مهارتهـاى اجتمـاعى)، توانـايى بيشبينى متغير ملـاكك يعنى كيفيـت 


\section{جدول Ү: ضرايب ركرسيون استاندارد نشده و استاندارد شده مدل ييش بينى كيفيت زندكى در مدرسه}

\begin{tabular}{|c|c|c|c|c|c|}
\hline \multirow{2}{*}{ سطح معنادارى } & \multirow{2}{*}{$\mathbf{t}$} & \multirow{2}{*}{ ضرايب استاندارد شده } & \multicolumn{2}{|c|}{ ضرايب استاندارد نشده } & \multirow[t]{2}{*}{ مدل } \\
\hline & & & خطاى معيار & B & \\
\hline$\cdot / \cdot 1$ & $|r / r|$ & & $9 / \pi V$ & $\Lambda F / \wedge \Delta$ & ثابت \\
\hline$\cdot / 1$. & $1 / 90$ & $\cdot /|r|$ &.$/ 914$ & $1 / \cdot 1$ & انجاموظيفه \\
\hline.$/ \cdot 11$ & $r / \Delta \Delta$ & ./194 & $\cdot / \Delta V Y$ & 1/49. & احترام به ديخر ان \\
\hline$\cdot /$ V91 & $\cdot / r \cdot F$ & $\%$ r. &.$/ 999$ & $\cdot / r \mid r$ & رعايت مقررات \\
\hline.$/ \cdots 9$ & $r / 9 F$ & - /MAF & . & $|/ 4|$ & فعاليت گروهى \\
\hline $.194 r$ & $\cdot / F \vee q$ & $\cdot / \cdot r$ & $\cdot / 499$ & $\cdot / \mathrm{VV}$ & تحمل يذيرى \\
\hline
\end{tabular}

دييخر بيرامى و موحدى همســو با نتايج اين مطالعه دريافتند كه آموزش إش

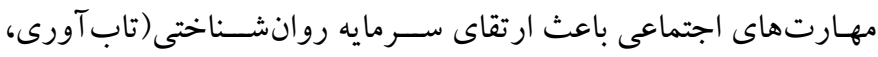

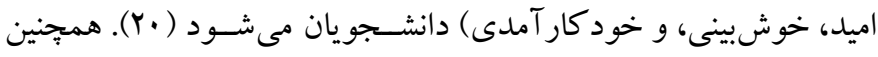

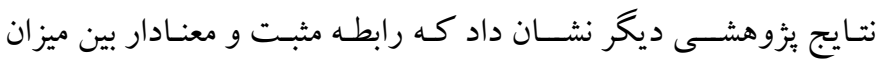
مهارتهاى اجتماعى و حمايت اجتماعى با ســلامت روانى دانشــجويان

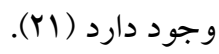
در تبيين نتايج به دسـت آمده در اين مطالعه مىتوان كفت كه مجهز

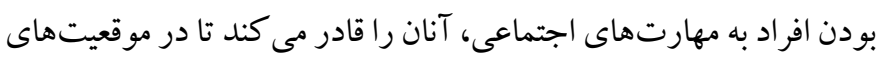
مختلف، واكنشهـاى منـاســـب و منطقى از خود بروز داده و از وقوع

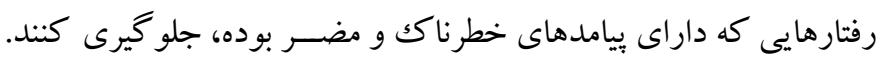

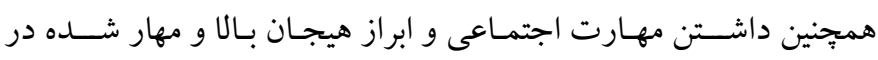

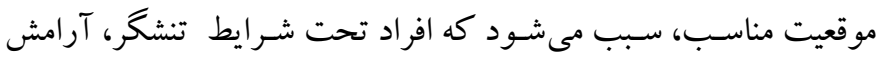
خود را حفظ كننــ (IY). بـايد توجه داشـت كه مهارتهاى اجتماعى،

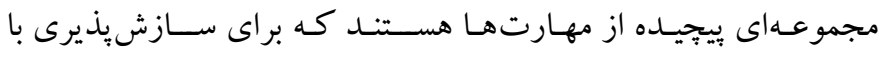

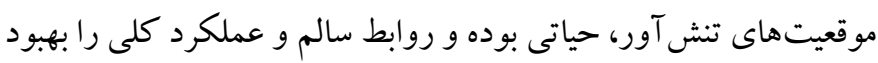

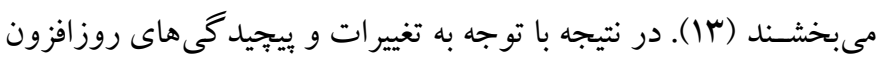
جـوامع، برخوردارى از مهـارتهـاى اجتمـاعى نقش مهمى در حسل

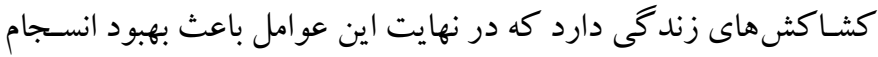

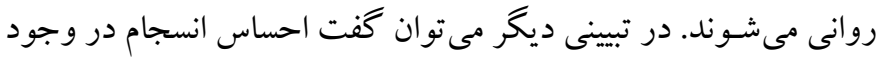

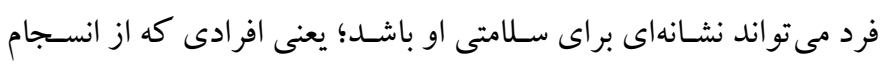

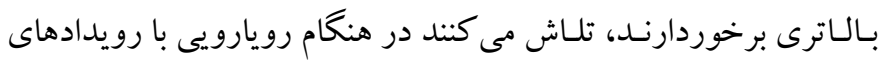

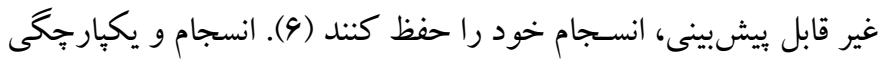
افر اد جامعه موجب ايجاد حس مسـئوليت، مشـار كت در مســائل جامعه، تلاش هر جه بيشتر در حل مشكلات، و رسيدن به اهداف جامعه كه همان

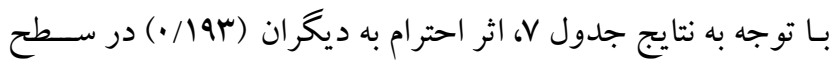

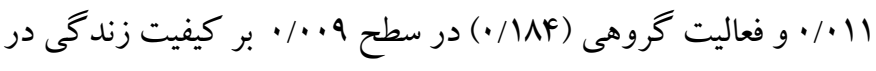

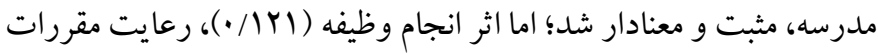

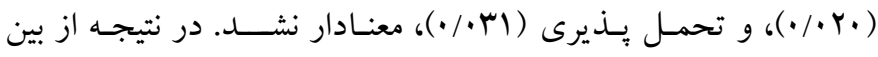

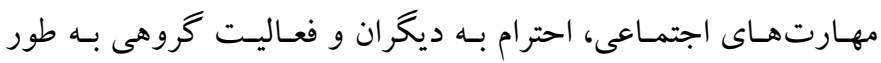

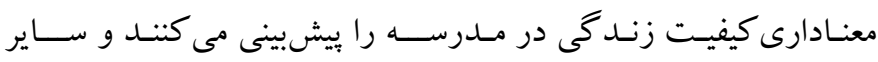

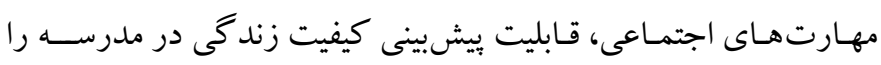

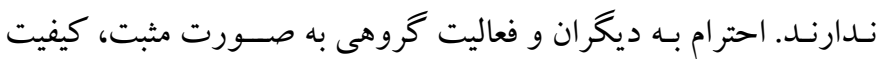

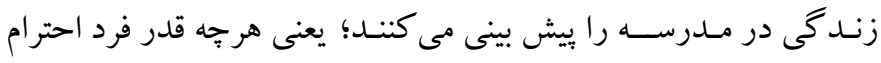

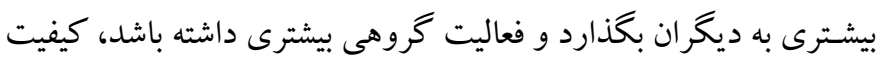
زندگى بهترى در مدرسه دارد.

\section{بحث و نتيجه كيرى}

هدف مطالعه حاضسر، بررسـى نقش مهارتهاى اجتماعى در بيشبينى

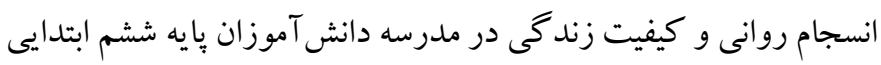

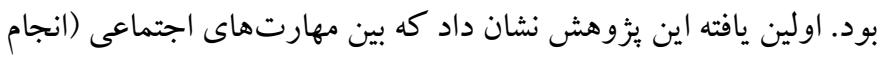

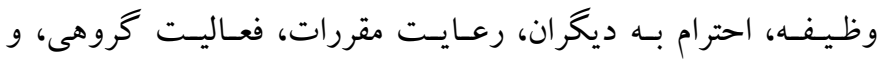
تحمل يذيرى) با انسجام روانى، رابطه مثبت و معنادارى وجود دارد. نتايج همجنين نشان داد مهارتهاى اجتماعى مى توانند انسجام روانى را به طور

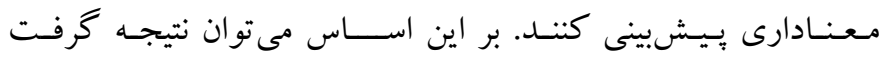

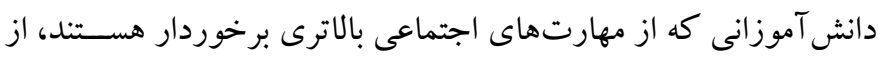

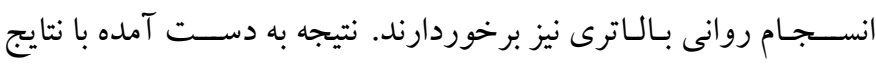

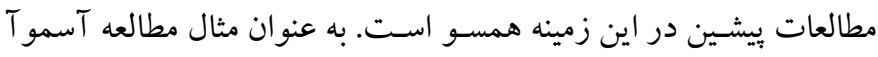

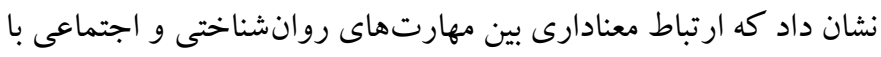
انسجام گروهى در عملكرد تيمهاى فوتبال وجود دارد (9 (). در مطالعهاى مهاى 
موضوع، توجيه كننده مناسبى براى ارتباط مهارتهاى اجتماعى با كيفيت

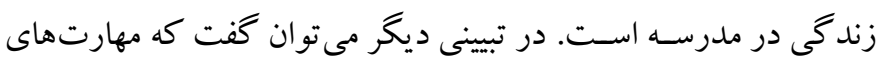

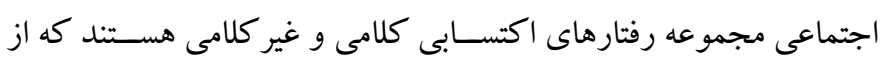

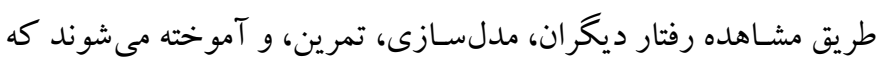

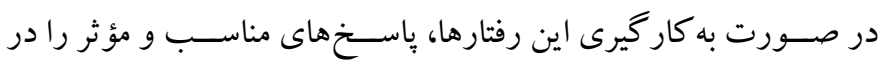
بردارند و موجب رشـد شخصى و اجتماعى افراد و بيشكيرى از مشكلات

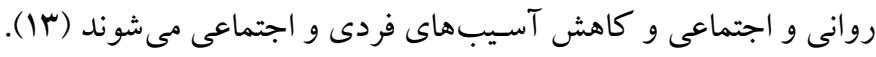

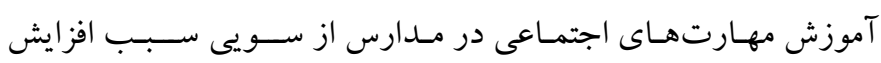

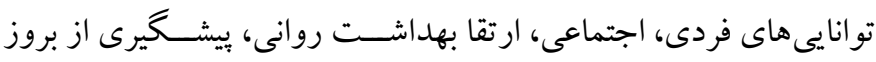

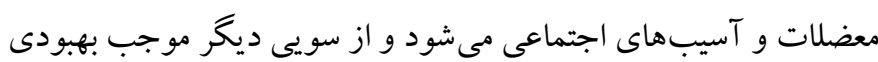

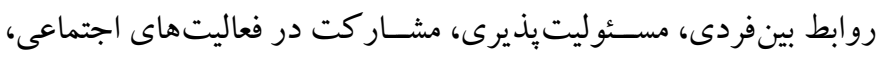

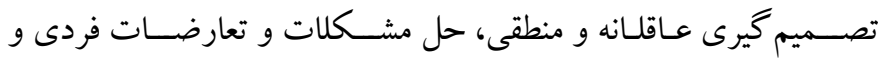

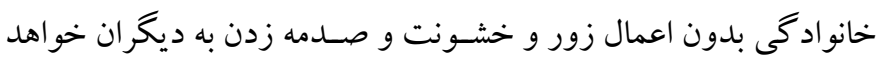

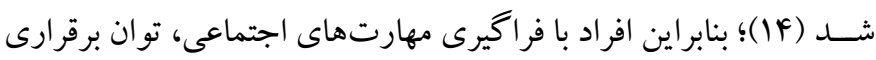
تعادل در زندگى اجتماعى خود را خواهند داشـت كه همين موضـوع در

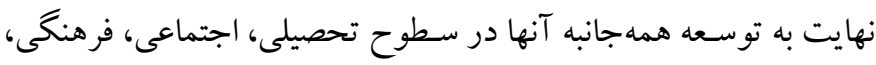

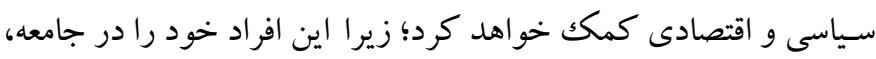
متعلق به اجتماع مى دانند. از محسدوديتهاى يثزوهش حاضــر جمع آورى اطلاعات بر اســاس

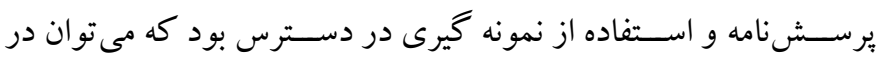

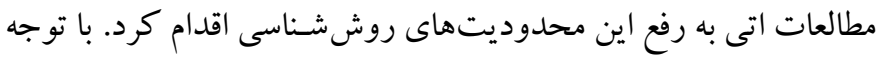

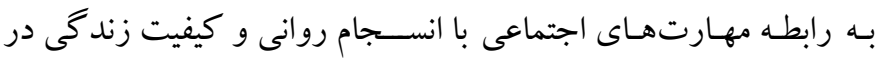

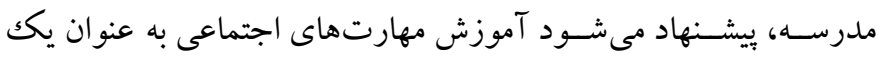

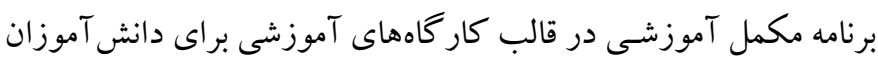

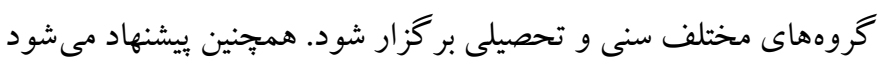

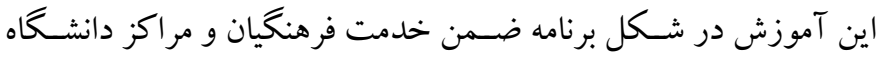
فرهنگيان به عنوان يكك واحد آموزشسى الزامى گنجانده شــود تا معلمها

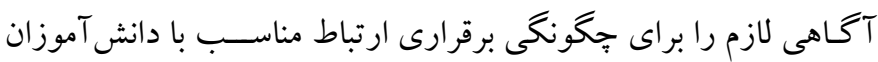

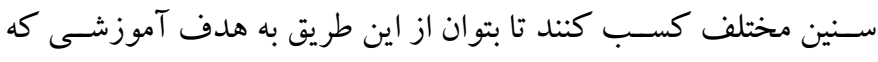

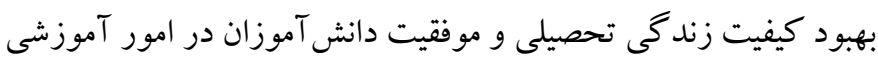
است در سطوح مختلف برسيم. در نهايت بايد توجه داشت همان طور كه

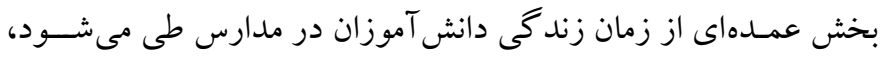

هدايت جامعه در مسـير بيشـفت و ترقى اسـت، مىشـود (19). از سويى

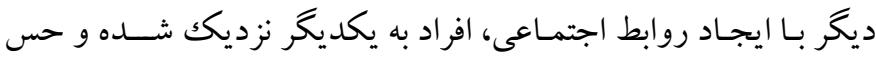

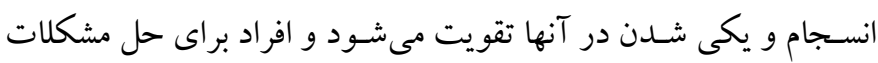

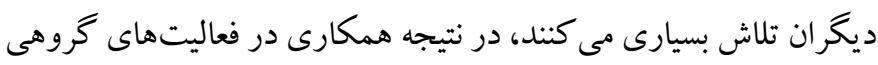

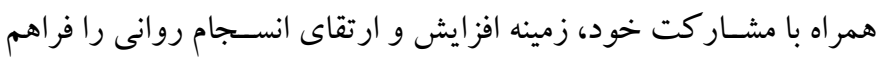

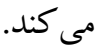
ديخر يـافته اين بزووهش نشــان داد بين مهارت هاى اجتماعى (انجام

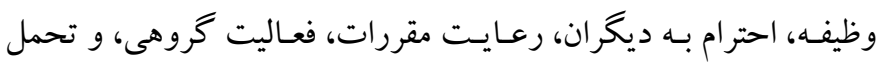

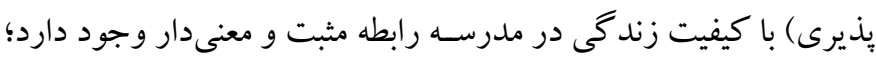

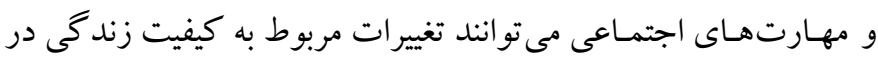

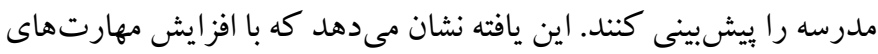
اجتماعى، كيفيت زندكى در مدرسـه دانش آموزان افزايش مى يابد. يافته

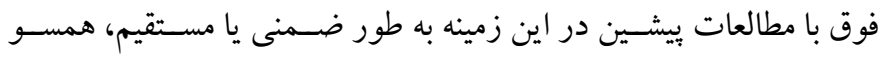
هسـت. به طور مثال نتايج يزووهش تيســون، لاوس، فلاورس، مورتيمر و

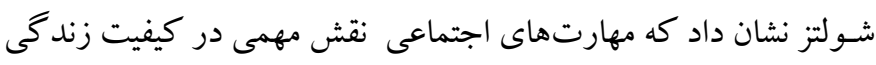

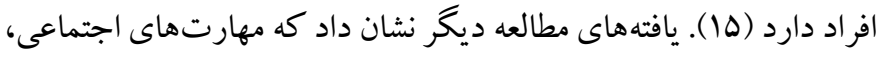
منبعى براى حمايت بيشستر اجتماعى، سطوح بايين تر افسردگى، و كيفيت

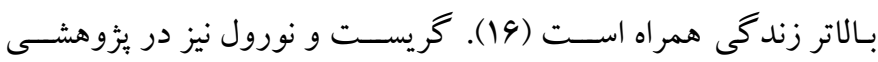

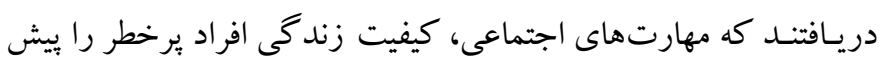

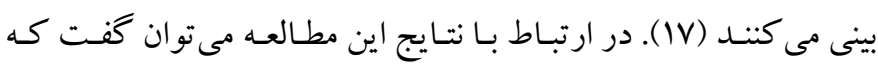

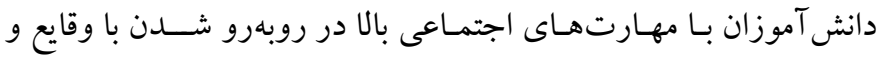

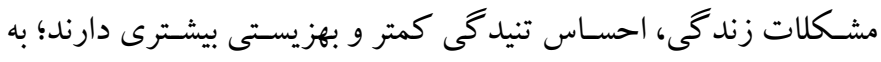

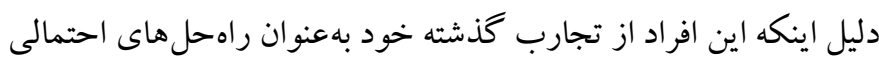

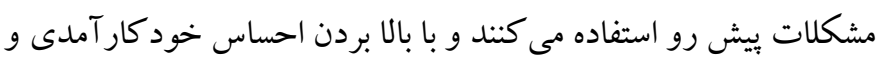
اطمينان به خود، شـاخص هاى سـلامت روان بالاترى را نيز نشـان مىدهند

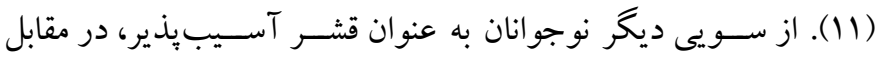

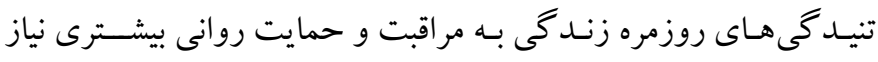

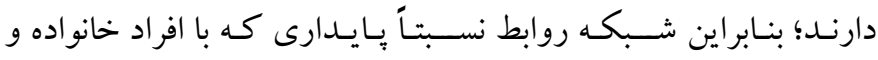

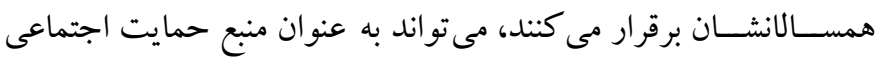
مهمى براى آنان در نظر كرفته شود (1N).

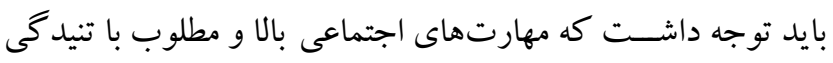

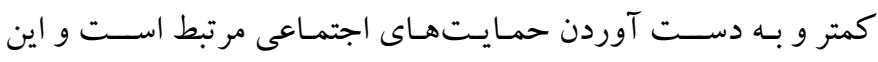




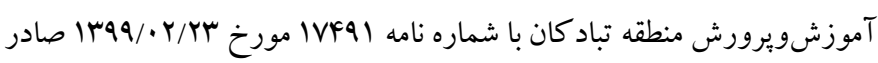

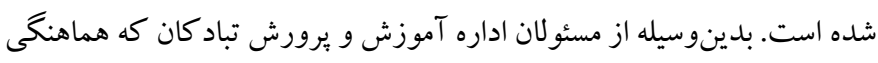
بـا مـدارس جهت آموزش و يُزوهش را انجام دادند و همجنين از كادر ادارى و

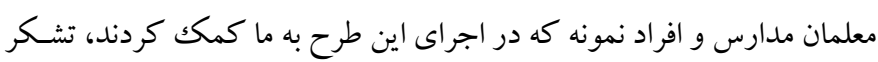
و قدردانى مى شود. تضاد منافع: نويسـند گان مقاله هيج گونه تعارض منافع رادر گزارش يافتهاى اين بزوهش كزارش نكردهاند.
توجه به كيفيت زندگى در مدارس مقاطع مختلف بايد از مؤلفههاى مهم و ضـرورى در برنامهريزىهاى كلان درسـى و سـياسـت هاى آموزش و يرورش مورد توجه قرار كيرد. تشـكر و قدردانى: اين بثوهش بركرفته از ياياننامه كارشــاسى ارشـد خانم

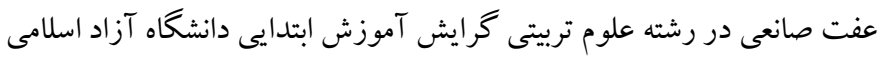
واحد فردوس با راهنمايى دكتر محمدرضا رئيسون با شماره تائيديه اسFم مورخ  


\section{References}

1. Soltani Shal R, Karshki H, Agha Mohammadian Sharbaf HR, Abde Khodaee MS, Bafandeh H. Evaluation of validity and reliability of the quality of school life questionnaire in Mashhad schools. Journal of Kerman University of Medical Sciences. 2012; 19(1): 79-93. [Persian]. [Link]

2. Kimura CA, Kamada I, Guilhem D, Monteiro PS. Quality of life analysis in ostomized colorectal cancer patients. Journal of Coloproctology. 2013; 33(4): 216221. [Link]

3. Zahed Babolan A, Karimianpour G, Dashti A. Role of life quality in school and academic self-concept on academic engagement in salas babajani fifth and sixth grade students. New Educational Approaches. 2017; 12(1): 75-91. [Persian]. [Link]

4. Naderi Nobandegani Z, Momeni Javid M, Hosseinian S. Effectiveness of training assertiveness behavior on life quality in school and social anxiety of females' students. New Educational Approaches. 2016; 10(2): 101-116. [Persian]. [Link]

5. Lynga P, Rosenqvist M, Langius-Eklöf A. The impact of sense of coherence on quality of life and self-care ability after an interactive patient education programme for patients with heart failure. Int J Pers Cent Med. 2011; 1(3): 501-506. [Link]

6. Madhu S, Siddiqui A, Desai N, Sharma S, Bansal A. Chronic stress, sense of coherence and risk of type 2 diabetes mellitus. Diabetes \& Metabolic Syndrome: Clinical Research \& Reviews. 2019; 13(1):18-23. [Link]

7. Hoseini M, Abdkhodai M. Effects of cognitivebehavioral fordyce happiness training on sense of coherence in patients with type 2 diabetes. J Neyshabur Univ Med Sci. 2017; 4(4):1-10. [Persian]. [Link]

8. Hoseyni M, Abdkhodai MS, Aghamohammadian Sherbaf HR. Role of mediating sense of coherence in relationship between duration and number of Physical complications of diabetes with mental health in Patients with type 2 diabetes mellitus. Horizon Med Sci. 2017; 23(4):311-317. [Persian]. [Link]

9. Kiamarsi A, Nee RIG. The relationship of a sense of coherence and alexithymia with life satisfaction in girl students with ADHD symptoms. Journal of school psychology. 2012; 1(1):76-92. [Persian]. [Link]

10. Persenius M, Rystedt I, Wilde-Larsson B, Baath C. Quality of life and sense of coherence in young people and adults with uncomplicated epilepsy: A longitudinal study. Epilepsy \& Behavior. 2015; 47(5):127-131. [Link]

11. Farhang Isfahani AR, Farhang Isfahani M, Mokhtari Yousefabad SE, Ebadi T, Haghighat S. The effect of social skills training on mental health, life quality and social adjustment of mothers with mentally retarded boy students. Scientific Journal Management System. 2018; 5(46):15-25. [Persian]. [Link]

12. Lau EX, Rapee RM, Coplan RJ. Combining child social skills training with a parent early intervention program for inhibited preschool children. J Anxiety Disord. 2017; 51(10):32-38. [Link]

13. Probst T, Geib C, Güroff E, Mühlberger A. Training the social skill "being able to demand" vs. training the social skill "being able to say no". A randomized controlled trial with healthy individuals. J Behav Ther Exp Psy. 2017; 57(11):1-5. [Link]

14. Otero TL, Schatz RB, Merrill AC, Bellini S. Social skills training for youth with autism spectrum disorders: a follow-up. Child Adolesc Psychiatr Clin N Am. 2015; 24(1):99-115. [Link]

15. Tyson PJ, Laws KR, Flowers KA, Mortimer AM, Schulz J. Attention and executive function in people with schizophrenia: Relationship with social skills and quality of life. Int J Psychiatr Clin Pract. 2008; 12(2):112-119. [Link]

16. Müller R, Peter C, Cieza A, Post MW, Van Leeuwen CM, Werner CS. Social skills: a resource for more social support, lower depression levels, higher quality of life, and participation in individuals with spinal cord injury? ACRM. 2015; 96(3):447-455. [Link]

17. Grisset NI, Norvell NK. Perceived social support, social skills, and quality of relationships in bulimic women. J Consult Clin Psychol. 2012; 60(2):293-299. [Link]

18. Barrera M, Atenafu EG, Sung L, Bartels U, Schulte $\mathrm{F}$, Chung J. A randomized control intervention trial to improve social skills and quality of life in pediatric brain tumor survivors. Psycho-oncology. 2018; 27(1):91-98. [Link]

19. Asamoah B. The role of mental toughness, psychological skills and team cohesion in soccer performance. Stellenbosch: Stellenbosch University; 2013. [Link]

20. Bayrami M, Movahedi Y. The effectiveness of social skills training on psychological capital among university students of tabriz city. Quarterly Journal of Social Work. 2015; 4(1):30-37. [Persian]. [Link]

21. Mazhabdar H, Hoseini M, Zahediasl M. Investigating the Social factors associated with the mental health of the faculty of social sciences students of allameh 
tabatabai university in 2010-2011. Pajouhan Scientific Journal. 2014; 12(2):55-63. [Persian]. [Link]

22. Gu X, Chang M, Solmon MA. Physical activity, physical fitness, and health-related quality of life in school-aged children. JTPE. 2016; 35(2):117-126. [Link]

23. Sancassiani F, Pintus E, Holte A, Paulus P, Moro MF, Cossu G, et al. Enhancing the emotional and social skills of the youth to promote their wellbeing and positive development: a systematic review of universal school-based randomized controlled trials. Clin Pract Epidemiol Ment Health. 2015; 11(1):21-40. [Link]

24. Krejcie RV, Morgan DW. Determining sample size for research activities. EPM. 1970; 30(3):607-610. [Link]

25. Keramati MR. The effect of participatory learning on the development of social skills and academic achievement in mathematics. Journal of psychology and Education. 2007; 37(1):39-55. [Persian]. [Link]

26. Mohebi Noredin Vand MH, Moshtaghi S, Shahbazi M. Relationship between Family Emotional Climate and Development of Social Skills and Achievement of Students Primary. Research in Curriculum Planning. 2011; 8(30):84-93. [Persian]. [Link]

27. Flensborg-Madsen T, Ventegodt S, Merrick J. Sense of coherence and physical health. testing antonovsky's theory. TSWJ. 2006; 6(5):2212-2219. [Link]

28. Ehteshamzadeh P, Sabri Nazarzadeh R, Me'marbashi Aval M. The relationship between sense of coherence and job performance with intermediation strategies of coping with stress and mental health. Scientific Journal Management System. 2013; 4(13):85-97. [Persian]. [Link]

29. Bourke S, Smith M, editors. Quality of life and intentions for further education. Annual Conference of the Australian Association for Research in Education. Adelaide, Australia; 1989. [Link]

30. Ahmadi H, Moeini M. An investigation of the relationship between social skills and high risk behaviors among the youth: the case of Shiraz city. Strategic Rssearch on Social Problems in Iran University of Isfahan. 2015; 4(1):1-24. [Persian]. [Link] 